\title{
THE EFFECTIVENESS OF USING GUIDED DISCOVERY IN TEACHING READING COMPREHENSION
}

\author{
Ida Zahara \\ State Islamic University of Raden Fatah, Palembang, South Sumatra \\ Ida.zahara@gmail.com
}

\begin{abstract}
The objectives of this study were to find out whether or not there was any significant difference in reading comprehension achievement between the students who were taught by using guided discovery and those who were taught by using conventional strategy to the eleventh grade students of MAN Arahan. This research was conducted through quasi-experimental method and used matching only pre-test post-test control group design. The population was 140 students of the eleventh grade of MAN Arahan in the academic year 2012/2013. Seventy students were chosen as the sample by using convenience sampling technique. The sample were assigned into two groups; the experimental group and the control group. Each group consisted of thirty five students. The data were obtained by reading comprehension test. A test was given both to the experimental group and control group before and after the treatment. The result of the test was analyzed by using matched t-test. The result of the study showed that there was any significant difference between eleventh grade students of MAN Arahan who were taught by using guided discovery and those who were taught by conventional strategy. The t-obtained was 4.52 at the significant level 0.05 in two tailed testing and $\mathrm{df}=21$, the critical value of $\mathrm{t}$-table is 2.080 . Since the value of t-obtained was higher than t-table, then the null hypothesis was rejected and the alternative hypothesis was accepted. It can be stated that guided discovery is effective in teaching reading comprehension, and can be used as the alternative technique for teaching reading comprehension to the eleventh grade students of MAN Arahan.
\end{abstract}

Keywords: guided discovery, reading comprehension achievement

\section{Introduction}

Nowadays, English is used as an international language for communication in the world. English is used in many fields such as; information and technology, economy, science, art, education, politics and so on. With the rapid development of science and technology, young generations (learner) need to develop their ability in many aspects in order not to be left behind. Mastery English is one way to reach it. In technology era, reading is one of the most important skills to develop knowledge beside listening, speaking and writing skills. Most of the sources of information and knowledge are show in internet, books, journals, TV and newspapers. McShane (2005) said that reading is the key to learning in all aspects of life. It provides access to get the information, knowledge, facilitates life-long learning, and opens doors to opportunity. Reading will help the readers improve their knowledge. In Indonesia, the government have done all efforts to integrate technology in English education (Habibi, Mukminin, Sofwan \& Sulistyo., 2017; Mukminin, Rohayati, Putra, Habibi, \& Aina, 2017; Prasojo, Habibi, Mukminin, Ikhsan, Taridi, \& Saudagar, 2017; Habibi, Mukminin, Riyanto, Prasojo, Sulistyo, Sofwan, \& Saudagar, 2018; Luschei, 2017; Yusuf et al., 2107).

To know the information of the printed text, the reader must have the ability to comprehend what they read. The more complex the text, the more work will be required of students to comprehend the text. Students who do not have background, abilities, or motivation 
to overcome the barriers presented in the complex text will have more difficulty comprehending the text. Students with poorly developed language skills and strategies and also the type of instruction that a student receives also affect reading comprehension.

Guided discovery as one of techniques that could help the students increase their reading comprehension. Creemers as cited in El-Kahlout (2010) states that guided discovery is one of the techniques happens when the students encounter unfamiliar situation and try to interpret the situation for understanding and comprehension. It is required flexible environment to help students participate and build their knowledge effectively. The research question is "is there any significant difference in reading comprehension achievement between the students who are taught by using guided discovery and those who are taught by using conventional strategy at MAN Arahan?"

\section{Conceptual framework}

Reading is a set of skills and an activity of getting information that involves making sense and deriving meaning from the printed words. Reading is a process how the readers interpret and understand what they read. According to Daiek and Anter (2004) Reading is an active process that depends on both an author's ability to convey meaning using words and readers ability to create meaning from them. To read successfully, readers need to constantly connect what they already know about the information to the words the author has written. Meanwhile, Hudelson in Murcia (2001) said reading is a transaction between the readers and the text to construct meaning that influenced by the readers' past experience, and language background as the readers' purpose for reading.

Based on the explanation mentioned above, it can be concludes that reading is a complex process that not just a process to let eyes physically run on the line by line or to pronounce the symbols and words from a printed words. Otherwise, reading is an intentional process of learning in order to gain information, to enhance vocabulary as well as to construct the meaning from printed text. Without comprehension, reading would be empty and meaningless. Reading comprehension refers to reading for meaning, understanding, and entertainment. It involves higher-order thinking skills and is much more complex than merely decoding specific words (Linse, 2005). When one has read a text with understanding, one is said to have comprehend it. Comprehension emphasizes the deliberate, strategic, problem-solving process of the reader as he or she engages with a text. Hence, the meaning a reader derives from a text is influenced by his or her own knowledge, experienced, and perceived purpose for reading. Moreover, according to Curtis and Kruidenier (2005) stated that: Reading comprehension is the process of constructing meaning from what is read. To comprehend, a reader must decode words and associate them with their meanings. To understanding the message from the text, it based on the readers' prior knowledge and their past experienced.

Reading comprehension requires an action on the part of the reader. That action involves the use of the existing knowledge that the reader has on the topic of the text as well as the text itself in order to create meaning. The problem in reading comprehension is making meaning from the text. The problem is solved by the intentional action of the reader, which includes the purpose for reading as well as the ability to draw upon prior knowledge that is relevant to the text. From the explanation above, it can be concludes that reading comprehension is how the readers construct the meaning of the printed words by using their thinking and their prior knowledge, so they get the idea and the information from what they have read and know the writers' purposes in the printed words.

According to Brown (2007) teaching is guiding and facilitating learning, enabling the learner to learn, setting the conditions for learning. Teaching is the specific act that showing or helping someone to learn how to do something, giving instructions, guiding in the study of something, providing with knowledge, causing to know or understand. Meanwhile, Moore in Moore (2005) 
defined teaching as "the actions of someone who is trying to assist others to reach their fullest potential in all aspects of development".

Teaching reading comprehension is important thing of English learning. The ability in reading clearly and efficiently contributes to the success of the learner in school and success later in every phase of life. Teaching reading comprehension is teaching to the learner to construct the meaning and to get the information from the text individually or in groups. The information can be which has related with their lesson or only for their pleasure. The English teachers have to share the material in reading based on their needed. Hopefully, the learner will interest in reading. Based that the material relevant to the students age and their level.

There are many activities or strategies can be created by teachers in teaching reading comprehension to improve their student achievement'. In this study, the writer tries to use guided discovery in teaching reading comprehension. Many definitions were given to guided discovery. Here are some definitions according to different points of view. According to Moore (2005) guided discovery is a means by which students engage in problem solving in developing knowledge or skills. In this strategy, teacher provide a situation that lets students identify a contradiction or uncertainty and then guide and assist them in finding a relationship between what they already know and discovered the new knowledge.

Moreover Adkisson in Westwood (2008) said that guided discovery is generally regarded as a motivating method, enjoyed by learners. Students learn independently, they interesting and curiosity to learn the new matesmarial guided by the teacher. In line with that, Mabrook as cited in El-Kahlout (2010) defined guided discovery as a process that the teachers use to introduce new materials, explore centers or areas of the classroom, and prepare learners for various aspects of the curriculum. This process gives students an opportunity to creatively and appropriate choices with regard to the focus of the discovery. Guided discovery is characterized by convergent thinking. The instructor devises a series of statements or questions that guide the learner, step by logical step, making a series of discoveries that leads to a single predetermined goal. In other words, the instructor initiates a stimulus and the learner reacts by engaging in active inquiry thereby discovering the appropriate response. The main features of guided discovery are learning how to learn through the process of discovery and the exploration of knowledge coupled with the responsibility of the learner. This helps the students to master the content needed for understanding.

According to Spencer in Schneider (2006), key features of guided discovery are:

- A context and frame for student learning through the provision of learning outcomes

- Learners have responsibility for exploration of content necessary for understanding through self-directed learning

- Study guides are used to facilitate and guide self-directed learning

- Understanding is reinforced through application in problem oriented, tasked based, and work related experiences.

There are so many advantages given in guided discovery. Westwood (2008) stated the advantages of guided discovery are the following:

- Students are actively involved in the process of learning and the topics are usually intrinsically motivating.

- The activities used in discovery contexts are often more meaningful than the typical classroom exercise and textbook study.

- Students acquire investigative and reflective skills that can be generalized and applied in other context.

- The approach builds on students' prior knowledge and experience.

- Independence in learning is encouraged. 
- It is claimed (but not proved conclusively) that students are more likely to remember concepts and information if they discover them on their own.

- Group working skill are enhanced.

Denton (2005) stated there are five steps in using guided discovery as follows:

1.Introduction and naming of materials

In this step, teachers use open-ended questions that encourage students to think about their past-experiences with the material and to share current observations.

2. Generating and modeling of ideas

Teacher invites students to think through how to use the material. Teacher begins with open-ended questions to get students thinking. When the brainstorming falters, the teacher challenges the students to go beyond their first ideas.

3. Exploration and experimentation

After students have generated a list of ideas and a few students have modeled ideas, it is time for students to independently explore the material. They tend to begin trying what was modeled. With encouragement, students soon start experimenting with new ideas.

4. Sharing exploratory work

After sharing and modeling ideas, students have an opportunity to share the work they have done to other students.

5.Cleanup and care of materials

In the last step, the teacher engages the students in thinking through modeling and practicing how they handled and maintained the materials then access them independently at a later time. Based on the explanation above, the steps are concentrated to the students' role in the classroom. By guiding from the teacher, the steps allowing the students to more active and more independent in exploring and sharing their own idea when teaching and learning process begin.

\section{Methodology}

In this study, the writer used a quasi-experimental method. The matching only pretest posttest control group design was used to investigate the significant difference in reading comprehension achievement between the students who are taught by using guided discovery and those who are taught by using conventional strategy to the eleventh grade students of MAN Arahan. There were two groups in this study. The first group was experimental group and the second group was control group. Both of groups were given pretest. After getting the result of the pretest, the writer matched the subjects in experiment and control groups who got the same score. Then experimental group get a treatment by using guided discovery strategy, while control group get a treatment by using conventional strategy. Finally, both of groups were given posttest.

\section{Research instruments}

Before doing the real study, the instruments were tried out to the eleventh grade students of MAN 2 Palembang with the total amount 30 students as the sample to find out the validity and reliability of the test. Treatments are done for twelve meeting. There are three texts used for the treatments, consisting of narrative, spoof, and hortatory exposition text. In each text, include four different titles. In narrative text consisting of: 1) The Strong Man, 2) Jonah, 3) The Lion and the Mouse, and 4) Miracle. In spoof text consisting of: 1) Vampire Bat, 2) An Old Man's Dying Request, 3) Weight Loss Program Story, and 4) The Zoo Job Story. Then, in hortatory exposition text consisting of: 1) Should Ads Banned from TV Program, 2) Corruption, 3) School Uniform Another Good Lesson, and 4) Agriculture. Time allocation for every meeting is $2 \times 45$ minutes, and the text given to the students started from very easy level to difficult level.

\section{Technique for analyzing the data}


In collecting the data, the writer used reading comprehension test. The purpose of the test was to know the result of teaching reading by using guided discovery strategy. Reading comprehension test in the pretest was administered before treatment and posttest was administered after treatment. The test items in the pretest were the same as those of posttest, because the purpose of giving them was to know the progress of students reading comprehension achievement before and after treatment. After got the scores of pre-test and post-test from students in experiment and control groups, the scores from the data will be analyzed by using matched t-test. This formula is used to compared the two mean obtained from two groups to determine whether or not any significant difference between the two mean scores is presented (Farhady \& Evelyn, 1982).

\section{Population and sample}

Population is the group of interest to the researcher, the group to whom the researcher would like to generalize the results of the study (Fraenkel and Wallen, 1990:68). In this study, the eleventh grade students of MAN Arahan in academic year 2012/2013 were used as the population. The number of eleventh grade students was 140, consisting of four classes; XI Science, XI Social 1, XI Social 2, and XI PAI. In each class consisting of 35 students.

Sample is a group in a research study on which information is obtained (Fraenkel and Wallen, 1990:66). For the sample of the study, the writer used convenience sampling technique. The total sample of this study was 70 students from the population, 35 students as experimental group (XI Science) and 35 students as control group (XI Social 1).

\section{Data analysis and discussions validity}

Validity means that the individual's scores from an instrument make sense, are meaningful, and enable the researcher to draw good conclusions from the sample she/he is studying to the population (Creswell, 2005). A test should be considered valid if it asks about something else.

There are two ways to check validity of the test, by validity test of each question item and content validity. Validity test of each question item is used to indicate whether the test item of the instrument in each question is valid or not. To know whether it is valid or not, the score of significance (r-output) should be compared with the score of $r$-table product moment.

In this study, the writer is going to analyze the validity of each question item with multiple choice questions. There are 60 multiple choice questions with $\mathrm{N}$ (sample) is 30 students. From students' answer, the correct answer is labelled 1 , and the wrong answer is labelled 0 .

From the result analysis of validity of each question item, it is found that there are 20 question items considered invalid, and there are 40 question items are considered valid since the scores of significance are higher than 0.361 .

Then, the writer also did content validity. Hughes (1989) states that a test is said to have content validity if its content constitutes a representative sample of the language skills, structures, etc., with which it is meant to be concerned. In order to know if the contents of the test items given were appropriate, the researchers suited them to content of the syllabus. Here, the writer used syllabus of Senior High School (SMA) and the specification of reading comprehension test, which contained the items that were necessary to test in reading comprehension. Selecting the appropriate text and items were used based on the syllabus that used in the school.

There are five texts used for the test, consisting of Fluffy Bunny Rabbit (8 questions), Why are Diazon and Dursban should be Banned (6 questions), A Small Experiment (7 questions), Home Schooling (7 questions), The Legend of Kesodo Feast (5 questions), and The Necessity of Salt (7 questions). Then, there are five indicator of the test consisting of; 1) to find main idea; 2) to find a detail information; 3) to find reference; 4) to find inference; 5) to find a vocabulary (synonym and antonym). 


\section{Reliability}

In this study, the writer found out the reliability of the test analyze by using internal consistency reliability; Kuder Richardson formula 21 (K-R 21) (Fraenkel and Wallen, 1990:135).

From the calculation, the writer found the result was 0.91. Fraenkle and Wallen (1990: 136) state that for research purposes a useful rule is that reliability should be at least 0.70 or preferably higher. Since the result of Kuder Richardson calculation was 0.91 it can be stated that the score of the try out test was considered reliable.

\section{Descriptive statistics \\ Students' pre-test and post-test scores in control group}

Based on analyzing the data from pre-test scores of control group, it was found that the minimum score was 47.5 , the maximum score was 75 , the mean score was 64.43 , and the standard deviation was 2.80 . Then, based on analyzing the data from post-test scores, it was found that the minimum score was 52.5 , the maximum score was 77.5 , the mean score was 67.61 , and the standard deviation was 2.80 .

\section{Students' pre-test and post-test scores in experimental group}

Based on analyzing the data from pre-test scores of experimental group, it was found that the minimum score was 47.5 , the maximum score was 75 , the mean score was 64.43 , and the standard deviation was 2.60. Then, based on analyzing the data from post-test scores of experimental group, it was found that the minimum score was 55 , the maximum score was 85 , the mean score was 71.14, and the standard deviation was 2.60 .

\section{Normality test on students pre-test and post-test scores in control and experimental groups}

Normality test is used to measure whether the obtained data normal or not. According to Basrowi and Soenyono (2007) state that the data can be classified into normal when p-output is higher than mean significant difference at 0.025 level. In measuring normality test, one sample Kolmogorov Smirnov is used. The normality test is used to measure students' pre-test score in control and experimental groups, and students' post-test score in control and experimental groups.

\section{Normality analysis of students' pre-test and post-test scores in control and experimental groups}

From the statistical analysis using normality test of Kolmogorov Smirnov, it was found that the significant value of the pre-test in control and experimental groups was 0.283 , it can be stated that the pre-test scores in both groups were categories normal since the p-output was higher than significant difference at 0.05 level.

Furthermore, from the statistical analysis using normality test of Kolmogorov Smirnov, it was found that the significant value of the post-test in control group was 0.506 and the significant value of the post-test in experimental group was 0.894 , it can be assumed that the post-test scores of the students' in control and experimental groups was categories normal since the p-output was higher than significant difference at 0.05 level.

\section{Homogeneity test on students pre-test and post-test scores in control and experimental groups}

Homogeneity test is used to measure the score obtained whether it is homogeny or not. According to Basrowi and Soenyono (2007), states that the score is categorized homogeny when the p-output was higher than mean significant difference at 0.05 level. The obtained data are 
achieved from students' pre-test and post-test scores in control and experimental groups. In analyzing the homogeneity test, levene statistics found in SPSS is used in this study.

\section{Homogeneity analysis of students pre-test and post-test scores in control and experimental groups}

Based on analyzing the data using levene statistics, it was found that the p-output was 1.000, it means that the sample of pre-test scores in control and experimental groups was categories homogeneous because the p-output was higher than mean significant difference at the 0.05 level.

Moreover, from the statistical analysis of post-test in both groups, it was found that the $\mathrm{p}$ output was 0.853 , it means that the sample of post-test scores in control and experimental groups was categories homogeneous because the p-output was higher than mean significant difference at the 0.05 level.

\section{Result of testing hypothesis in measuring mean significant difference}

Based on the result of post-test in experimental and control groups, the writer calculated the scores from both group used matched t-test formula to find out whether or not any significant difference in reading comprehension achievement between the students who are taught by using guided discovery and those who are taught by using conventional strategy to the eleventh grade students of MAN Arahan.

From the result analysis measuring significant difference, it is found that the mean difference between $\mathrm{X}_{2}$ (67.61) of post-test in control group and $\mathrm{X}_{1}$ (71.14) of post-test in experimental group was 3.53 point. Based on the calculation using matched t-test formula, the value t-obtained (4.52) was higher than critical value of t-table (2.080) at the significance level p < 0.05 in two tailed testing. Consequently the null hypothesis (Ho) was rejected and the alternative hypothesis $(\mathrm{Ha})$ was accepted. It means that there was significant difference in students' reading comprehension achievement between the students who were taught by using guided discovery strategy and those who were taught by using conventional method, and it was indicate that guided discovery technique was effective to apply in teaching reading comprehension to the eleventh grade students of MAN Arahan.

\section{Conclusion}

Based on the findings of the study, the writer concludes that: First, there was significant difference between students who were taught by using guided discovery and those who were taught by using conventional strategy. It can be seen from the gain scores of post-test in both experimental and control groups, the mean difference between $\mathrm{X}_{1}$ (67.61) of post-test in control group and $\mathrm{X}_{2}$ (71.14) of post-test in experimental group was 3.53 point. Second, the result of matched t-test shows that the t-obtained was 4.52. Therefore, the value $\mathrm{t}$-obtained was higher than the critical value of $\mathrm{t}$-table (2.080) at the significance level $\mathrm{p}<0.05$ in two-tailed testing. From the result, it was conclude that, the null hypothesis $(\mathrm{Ho})$ was rejected and the null alternative $(\mathrm{Ha})$ was accepted. Third, guided discovery technique was effective to teaching reading comprehension to the eleventh grade students of MAN Arahan.

\section{References}

Basrowi \& Soenyono. (2007). Metode Analisa Data Sosial. Kediri: CV. Jenggala Pustaka Utama.

Brown, H .D. (2007). Principles of Language Learning and Teaching $\left(5^{\text {th }} \mathrm{ed}\right)$. USA. Pearson Education, Inc.

Creswell, J.W. (2005). Educational research: Planning, conducting, and evaluating quantitative and qualitative research $\left(2^{\text {nd }} E d\right)$. New Jersey. Pearson Education, Inc. 
Curties, E. M., \& Kruidenier, J. R. (2005). A summary of scientifically based research principles teaching adults to read. National Institute for Literacy. Retrieved from http://lincs.ed.gov/publications/pdf/teach_adults.pdf. on January, $13^{\text {th }} 2013$.

Daiek, Deborah, B., \& Anter, N.M. (2004). Critical reading for college and beyond. New York: McGraw-Hill.

Denton, P. (2005). Learning through academic choice. Northeast Foundation for Children, Inc.

El-Kahlout, Y.A. (2010). The effectiveness of using guided discovery on developing reading comprehension skills for the eleventh graders in Gaza. Published M. A Dissertation, Al- Azhar University. Retrieved from:

http://www.google.com/search?q=THE+EFFECTIVENESS+OF+USING+GUIDED+ DISCOVER\&ie $=u t f-8 \& o e=u t f-8 \& a q=t \& r l s=$ org. mozilla:id:official\&client $=$ firefox-a..$\quad$ on January, $2^{\text {nd }} 2013$.

Fraenkel, J.R., \& Wallen, N.E. (1990). How to design and evaluate research. USA. McGraw-Hill.

Habibi, A., Mukminin, A., Sofwan, M., \& Sulistiyo, U. (2017). Implementation of classroom management by English teachers at high schools in Jambi, Indonesia. Studies in English Language and Education, 4(2), 172-189.

Habibi, A., Mukminin, A., Riyanto, Y., Prasojo, L.D., Sulistiyo, U., Saudagar, F., \& Sofwan, M. (2018) Building an online community: Student teachers' perceptions on the advantages of using social networking services in a teacher education program. Turkish Online Journal in Distance Education, 19 (1), 46-61.

Hossein, F., \& Hatch, E. (1982). Research design and statistics for applied linguistics. London. Newbury House Publisher, Inc.

Hughes, Arthur. (1989). Testing for the language teachers. New York. Cambridge University Press.

Linse, C. T. (2005). Practical English language teaching: young learners. Singapore. McGraw-Hill.

Luschei, T. (2017). 20 Years of TIMSS: Lessons for Indonesia. Indonesian Research Journal In Education $\mid$ IRJE|, 1 (1), 6-17.

McShane, S. (2005). Applying research in reading instruction for adults first steps for teachers. National Institute for Literacy. Retrieved from: http://lincs.ed.gov/publications/pdf/applyingresearch.pdf. on January, 13th 2013.

Mukminin, A., Rohayati, T., Putra, H. A., Habibi, A., \& Aina, M. (2017). The Long Walk to Quality Teacher Education in Indonesia: Student Teachers' Motives to become a Teacher and Policy Implications. Elementary Education Online, 16(1), 35-59.

Moore, K. D. (2005). Effective instructional strategies from theory to practice. USA. Saga Publication, Inc.

Murcia, M.C. (2001). Teaching English as a second or foreign language (3th ed). USA. Heinle \& Heinle, Thomson Learning, Inc.

Prasojo, L. D., Habibi, A., Mukminin, A., Muhaimin, Ikhsan, Taridi \& Saudagar, F. (2017). Managing Digital Learning Environments: Student Teachers' Perception on the Social Networking Services Use in Writing Courses in Teacher Education. The Turkish Online Journal of Educational Technology, 16 (4), 42-55.

Schneider, D. K. (2006). Guided discovery learning. Retrieved from: http://edutechwiki.unige.ch/en/Guided_discovery_learning. on February, $6^{\text {th }} 2013$.

Yusuf, Q., Yusuf, Y., Yusuf, B., \& Nadya, A. (2017). Skimming and scanning techniques to assist EFL students in understanding English reading texts. Indonesian Research Journal in Education |IRJE |, 1(1), 43-57.

Westwood, P. S. (2008). What teachers need to know about teaching methods. Australia. ACER Press. 